\title{
The Metamorphosis of the Significance of Death in Revolutionary Times: Mohammad Rabie's Otared (2014)
}

\author{
Walaa Said
}

All hope abandon, ye who enter here. Divine Comedy, Dante Alighieri

\section{Introduction}

Although violent death (and its related themes of fear, anger, mourning, loss, pain, torture, and despair) has been ever-present throughout the Middle East since 2010 , both as a trigger and an outcome of the mass-mobilization in the region, it has not been adequately addressed by various domains of intellectual discourse. In her 2015 article "Death and Martyrdom in the Arab Uprisings: An Introduction," Amira Mittermaier criticizes the lack of anthropological research on death during this period (2015, p. 588). Furthermore, she urges her readers to reconsider "death as an analytical lens to think about street politics" (Mittermaier 2015, p. 587). Moving away from the designation "Arab Spring," which tends to romanticize the extensive popular political mobilization in public spaces across the Arab world, Mittermaier's reminder provides a chance to scrutinize the effects of the intense incidents of violence and death and their affective consequences on reproducing and disempowering both the individual and the masses. The article analyzes selected scenes from Mohammad Rabie's novel Otared (2014) in an effort to trace the effects of violent death on bodies and to examine how those bodies

\footnotetext{
W. Said $(\bowtie)$

Institut für Anglistik und Amerikanistik, Philipps-Universität Marburg, Marburg, Germany

e-mail: walaa.said@staff.uni-marburg.de
}

R. Ouaissa et al. (eds.), Re-Configurations, Politik und Gesellschaft des Nahen Ostens, https://doi.org/10.1007/978-3-658-31160-5_15 
translate and internalize such deaths' effects through the emotions of anger, hope, fear, and performative horror.

\section{Violent Death: Between the Derealization of the Living and the Martyrization of the Dead}

Violent death is medically defined as a death caused by intentional use of physical force or power, threatened or actual, against oneself, another person, a group, or a community (Norris 1992). As Rynearson explains, violent death thus has three dimensions, the "three Vs": violence, violation, and volition. Correspondingly, dying is either "injurious," "transgressive," or resulting from "irresponsible negligence" (2013, p. 21). In turn, these three dimensions mandate "retaliation," "retribution," and "punishment" and work as "an inherent counter-story to the [three] V's of violent dying" (Rynearson 2013, p. 21). Those three Vs interfere with the mourners' acceptance of death, causing what is called a "complicated grief," "a form of bereavement marked by elevated and persistent separation distress, seriously impaired functioning, and difficulties 'moving on' with life following the loss of a loved one" (Currier et al. 2006, p. 404).

Since January 25, 2011, Egypt has witnessed bloody clashes, chaotic killing, sniping, and injuries at the center of its capital aired on television screens or circulated via social media. Given such a state of emergency, where death is visible and fear becomes both permeable and ubiquitous, it is useful to briefly explore how death is facilitated, permitted, and received, and Judith Butler's concept of "derealization of the living" provides an apt lens for this exploration.

In Precarious Life, Judith Butler describes at length how violence and death are facilitated and justified. While she mainly criticizes the ideas that allow US society to justify suspecting and killing "Others" in the context of the War on Terror, it is quite helpful to extend her argument to include other tense political situations in which systematic violence is a means to control widespread fear or cover national vulnerability. Life, accordingly, becomes a privilege that is not granted to everyone equally. On a discursive level, this privilege is bestowed upon those who demonstrate ethnic, political, and/or social commonalities within the dominant group, whereas people who lack such commonalities are denied that privilege. That said, there are those whose lives are considered valuable and, hence, "grievable." And there are those who, because of cultural or political difference, unfamiliarity, or disputation, are distanced and othered; their lives are not valuable and their death is ungrievable (Butler 2006, p. 34 ff.). In Butler's words, this discourse derealizes those lives, rendering them "unreal." So when violence 
is exercised against the invisible, "it fails to injure or negate those lives since those lives are already negated" (Butler 2006, p. 33). Accordingly, those derealized lives are "neither alive nor dead, but interminably spectral" (Butler 2006, p. 33 f.). Those situations of political fragmentation beget what Butler calls "violence of the derealization" (Butler 2006, p. 33), a vicious cycle of violence that is nearly impossible to break, as it targets spectral bodies. Within this discourse, exerting violence against or even killing such spectral bodies is not considered a crime; it never happens. The process of derealizing bodies mirrors the state's fear; therefore, the process constitutes a case of othering, in which the spectral bodies are scapegoated for the loss of security.

Since grief is essential for the living, not only to process death, but to assure them of the value of their lives and thus their deaths, the total absence of united national grief results in a "national complicated grief." The spread of the arbitrary killings that took place on public spaces, intentionally at times, confirmed the unworthiness of individual lives and gave root to intense fear. In a fragmented political context that lacks national grieving, renaming the dead "martyrs" ( $\operatorname{sh} u$ had $\bar{a}$ ') serves as an antidote to their derealization. This retrospective process of martyrizing the dead offers a healing solution. While the dead themselves cannot benefit from being upgraded to martyrs, martyrization of dead has allowed bereaved survivors to find meaning for the death of their loved ones, and perhaps, for the dead's lost lives.

Amira Mittermaier characterizes martyrdom positively as "about giving one's life for a cause, a better state of affairs, and simultaneously ... about one's fate in the afterlife" (2015, p. 588). By contrast, in her introduction to Martyrdom in Literature, Friederike Pannewick problematizes the concept as "a voluntary act staged as a response to the collective experience of suffering, fear and utter confusion" (2004, p. 1). Although the previous definitions stress the intentions of the dead, which are impossible for a witness to know for certain unless the dead left behind a note, martyrization cannot be accomplished without the living sharing the same suffering and/or cause. While both Mittermaier and Pannewick suggest the purposefulness of the dead, the latter not only stresses collective weariness with the socio-political contexts, but partially explains protestors' insistence on continuing to occupy the public squares despite the random killings. However, for a person to count as a martyr, his or her death should be witnessed or attended by an "audience" (Mittermaier 2015, p. 588) and accepted by the local community of survivors. Thus, martyrdom "is a label assigned retroactively" (Mittermaier 2015, p. 588): in order for this process to be completed, the life of the dead requires to be examined and idealized, and transformed into a legacy circulated to keep the memory alive. Although the factors of witnessing and/or intentions 
were not satisfied in many cases during the clashes, martyrization continues to be widely practiced. It has been convenient for protesters and political activists to extend the label of martyr to anyone shot or killed during clashes and, equally important, to one's political allies. At the outset, this grand narrative works as a coping mechanism for this new level of terror and heightened death rate, serving "as tools for holding the state accountable, as mobilizers of continuous protests, and as a source of inspiration" (Mittermaier 2015, p. 586).

On another note, Mittermaier points to the fact that "death does not erase hierarchies" (2015, p. 594), and not all martyrs are memorialized equally: some become famous and are branded through different media, while others are consigned to oblivion, or denied the rank altogether. ${ }^{1}$ Despite the intention of finding consolation by martyrizing the dead, the discourse of martyrdom contributes more to the state of the derealization of the living, who are derealized twice. The hierarchy of death and martyrdom denies that all lives are valuable and therefore grievable. Evidently, the interrelationship between violence and the revolutionary act problematizes death as well as life and keeps lives "interminably spectral." As much as martyrization becomes a way to grant death meaning, the intensity of fear remains: silently lurking and paving the way for the police and/or the military state to take over and, most importantly, eradicate revolutionary bodies from public spaces. In short, empty public spaces subjected to military discipline have been haunted by the spectral bodies of the dead and the permanent stain of fear.

\section{Death and Fear in Post-2011 Dystopias: The Example of Mohammad Rabie's Otared}

Mohammad Rabie's novel Otared is graphically violent: it includes intense descriptive scenes of rape, necrophilia, and homicide. Dead, tormented bodies and bodies in terror are not only the pivotal theme in the novel; this is the text's tool for demonstrating a deconstructive reading experience of the idealized uprising. In this novel, published shortly after the dispersion of the Rabaa' sit-in of 2013, the uprising of 2011 is a point of departure, or better, a momentum, for the text's fragmentation that implodes any possible discourse of hope. In the narrative, January 25, 2011 instigates cycles of dystopic futures. The novel tackles the theme of sniping as the main reason for the deaths during the first eighteen days. Otared is a complex work, in which the violent death scenes are gravely elaborated. Through a circular labyrinth, Otared comprises three main temporal threads: $2025 \mathrm{AD}, 2011 \mathrm{AD}$, and $455 \mathrm{AH}(1063 \mathrm{AD})^{2}$ in five parts (with alternating 2011 and 2025 parts grouped around the central 455 section), named after 
these points in time, besides a prologue, which takes place some time before 2011. The novel is narrated in a line that cuts across the three temporal lines: a 2025 grotesque under occupation Cairo, taking most of the narrative space; a briefer section during 2011 "revolutionary" Cairo; and a 455 AH early medieval apocalyptic Cairo, at the center of the narration. Once the narration passes the medieval portrayal of Cairo, the entire tone and vocabulary intensifies and recapitulates the metaphysical idea of hell as an interpretative paradigm of the following course of actions. The characters portrayed in the 2025, 2011, and 455 sections remain separated throughout the narration except for the final part, titled "2025," in which Otared, the protagonist of the prologue and the 2025 time line, meets Zahra, the protagonist of the 2011 segments. The narrative voice is polyphonic, with both first-person and omnipresent narrators. In the following, my analysis will focus on scrutinizing how, in a revolutionary context, the narrative techniques strip any glorified significance from the moment of death and render it a mere public performance of terror.

\section{1: Hope as the Grim Reaper}

In the 2011 narrative thread, Rabie uses two themes to explore how lives are derealized. First, he dramatizes the random killings committed by snipers on rooftops overlooking Tahrir Square during the eighteen days of the uprising. The narrative demonstrates the effects of the extensive, arbitrary killings on the streets of Cairo on which people are entrapped, as death is inescapable. From another angle, Rabie presents the derealization of lives through the anonymity of the dead. All the sub-stories in this narrative thread center on dead bodies without ID cards, the state official document of people's identification, visibility, and surveillance. For the "[m] any in this country [who] had no ID; many were too low down the scale to own one; [and] many had lost theirs on purpose" (Rabie 2016, p. 177). These scenes highlight the symbolic existence of the ID as a reference to the system and its concept of "humanity." In the eye of the state, humanity is synonym to citizenship based on a notion of complete docility and obedience. Without an official ID, both citizenship and human individuality are erased. Thus, those who decided to dispose of their IDs might escape the firm grip of state's surveillance, but they lose any chance of personal visibility; their lives and their deaths are, therefore, not accountable or even valuable. Dramatizing those two themes touches upon how the system derealizes lives and, as a corollary, how people deeply internalized this systematic derealization. 
Moreover, those two themes dismiss any glorified interpretations of death. In this context, death is not meant to be natural; rather, it is executed through killing and visibly deformed bodies in public spaces. Rabie captures the moments of extreme fragility and vulnerability that occur when citizens are exposed to those scenes of death. In other words, through emotions of terror and helplessness, the "2011" sections reproduce an alternative history of the first eighteen days. Accordingly, the novel renders revolutionary demonstrations distant and invisible while foregrounding death and deformed corpses. The text brushes aside the role of the political activists, instead spotlighting marginal characters and their individual confrontation with the commonality of death. The image of the public space as a festive mulid $^{3}$ is depicted as a space of fear. ${ }^{4}$

On another level, the novel's 2011 narrative thread is concerned with portraying the firsthand experiences of marginal unpoliticized characters from different social classes. The narrative thread of the middle-class characters Insal and Zahra examines the death of the unidentified from another perspective, in which dead bodies affect living ones. As Cairo goes through chaos and paralysis during the first eighteen days of the uprising, Insal, a teacher, finds himself responsible for his four-year-old student, Zahra, after she is left behind with no relatives or family to contact. Insal takes Zahra to live with him and his wife Layla, who is four months pregnant. Because he has never met Zahra's father, Insal decides sorrowfully to take the little girl on a journey through Cairo's morgues, which are packed with dead bodies, hoping to find her disappeared, "unknown" father. Insal's experience in the streets of Cairo exhibits how civilians inherited the system's way of derealizing the living. On his way home after a long day of searching, Insal watches civilians chase a man who is thought to be a thief because he is not carrying an ID. The man has been hit and tortured. When he is about to escape, Insal, taking him for a thief too, helps the crowd to grab him again. It takes only a few minutes until the man is hanged on a streetlight ( $\operatorname{Rabī}^{-} 2014$, p. 159). Insal later approaches the body and observes that " $[t]$ he nails were clean and the fingers well-formed. Unable to resist" (Rabī` 2014, p. 159). This man was most probably not a thief; his mistake was to walk on the streets of Cairo without an ID while people are in a state of fear and doubt. Ironically, in Tahrir Square, where people are expressing their anger and shattering the old barriers of fear of the regime, fear becomes the predominate emotion that dictates people's action outside the revolutionary spaces. Arriving home, Insal is unable to verbalize his own fear caused by what he has seen. In a moment of breakdown, he beat at his temples. He tugged at his hair. He covered his mouth with his hand and started to scream. He jumped up and down. He bit his fingers. He gripped his shirt and tugged at it violently, trying to rip it. Then he started slapping his face with a 
relentless rhythm, a slap every two seconds, one slap after another, striking harder with each one ... by the end each blow seemed to flood the scene before him with a bright light ... after a quarter of an hour of violence, he settled (Rabī' 2014, p. 159 f.)

Traumatized and likely suffering survivor's guilt, Insal inflicts violence on his own body. An example of the middle class, he is another marginal character who has never before encountered violent death in public. Before encountering the hanged man and the bodies of gunshot victims in the morgues, Insal has only witnessed "peaceful" deaths: "the bodies of people he knew who had slipped quietly away after sickness or in their sleep" (Rabī' 2014, p. 162).

All are exposed to rape, violence, death and deformed bodies of other marginal individuals. The exposure of this sudden severe violence disrupts their former contentment. The thin veil of security that their marginal existence provides them is abruptly and violently torn.

A closer look at the narrative perspective will help us to understand how the mood of obstruction and the sense of entrapment are expressed. The two parts titled "2011" share an omnipresent narrator that comments nonchalantly on the first eighteen days of the uprisings where "[t]he people out in the streets were angry. Murder was abroad" ( $\operatorname{Rab}^{-}{ }^{-} 2014$, p. 164). This third-person voice is not passively narrating selective death scenes, but it exercises the authority of explaining what lies behind these scenes and commenting on the characters and events. In one early instance, the narrator unveils the master plan behind the sense of torment and death that unfolds later, saying:

[n]o one realized that what had happened and what would happen thereafter was preordained, that the hell they lived in was perfectly normal, was in fact a hell that recurred elsewhere and often, and that all these things were a punishment (Rabī’ 2014, p. 154).

This early articulation briefly introduces the central notion of Rabie's political dystopia. Rabie borrows the Islamic concept of hell and dramatizes it. While, in Islamic theology, hell is a place that awaits the disobedient and nonbelievers in the afterlife, Rabie decides to design his own version of hell as an earthly place and eliminates any possibility of salvation. In consequence, Egyptians are the inhabitants of an eternal hell, where they are punished and doomed for eternity. The plot's twist is that the hell's inhabitants are unaware of living there; they mistakenly believe that they finally are able to demonstrate agency and topple a regime. This dystopian construction completely dismantles the uprising's status as a glorified act of resistance, rendering it absurd, as no revolutionary acts are expected in a traditional, theological hell: "There would be no victory today. There'd be no victory here, ever"' (Rabī' 2014, p. 165). In Rabie's nihilistic 
vision, life is stripped of meaning, and death, in this sense, is a torment to the living, void of any glory and heroism.

\section{"2025": “Marters of the Reverlooshun!"}

Death becomes conventional in public spaces, exactly as the narrator anticipates in the "2011" section. Fear is normalized. Brutal killings become an integral part of daily life against a backdrop of a cumbersome political situation. In the " 2025 " parts, fourteen years after a failed uprising, the spirit of political activism and the ambition of a possible political reformation are demolished. Moreover, Cairo has been occupied by the mysterious "Knights of the Republic of Malta," 5 who have divided it into Western and Eastern sectors.

Otared's and his colleagues' usage of "resistance" highlights the term's ambiguity and its problematic aspects. By their definition, resistance means "safeguarding the state" in which "the life of the average citizen [is] worthless when measured against the value of safeguarding the state" (Rabī' 2014, p. 72). Moreover, at one of their secret meetings, Otared describes the final plan set in motion by Sulayman Madi, a top Resistance leader, to oust the Knights of Malta. In short, this plan consists of enjoining civilians to revolt against the occupiers and kick them out by disseminating "pure panic" (Rabī' 2014, p. 67) among civilians, which the Resistance would blame on the occupiers. Madi goes on to explain how panic would be spread:

[T] he streets are going to be full of murder. It will be a crime without punishment ... killing without rhyme or reason. The fragile barrier of security ... will collapse without warning, and it is at that moment that the people will have no option but to rise up ... there are no restrictions to what you can do-select your victims with total freedom. Men and women, children and the elderly, it's all the same. It will be easy because you will be concealed (Rabī' 2014, p. 68).

This vicious plan aggrandizes the derealization of the "average citizens" and the systematic enshrouding of their existence. The overriding purpose of the Resistance movement is to expel the occupiers in order to restore authority to Otared and his cohort. The conflict, in this portrayal, is restricted between two poles of power over governing Egypt. This "national" resistance, in this sense, is a way to monopolize authority and surveillance and, moreover, to narrow the significance of "nation."

Ironically, in this plan, the envisaged dead "average citizens" are not considered "martyrs"; this status will be reserved for members of the Resistance. In the same meeting, they remember the shootings that happened on the "Day of 
Rage" in 2011. For Otared, Madi and their companions, the January 25, 2011 and the following days until the resignation of Mubarak are called the days of "troubles" (Rabī' 2014, p. 70), ${ }^{6}$ or mockingly "the reverlooshun" (Rabī' 2014, p. 72), in which sniping was an "attempt to frighten people and get them to go home" (Rabī' 2014, p. 70). However, those "days of trouble" still conjure up a painful memory of their injured pride, when the people dared to burn down police stations and demanded the end of injustice. From 2011 to 2023 (a mix of factual and imagined events), this random shooting never stops; on the contrary, "killing was permitted [later on] to dispose of terrorists, troublemakers, fifth columnists, and demonstrators, with the unconditional support of the people, the prosecutor general, and the judiciary. Indeed. Truly wonderful days..." (Rabī' 2014, p. 70 f.). "The unconditional support of the people" draws a direct connection between the masses' complicity in the state violence (inflicted on political opponents in an illusion of maintaining a fragile, conditional security) and their entitlement to punishment for their complicity.

As one of the best snipers, Otared plays a major role in "Operation Pure Panic," where he is stationed on one of the high buildings in downtown Cairo, where he hunts "average" citizens. Quite surprisingly, after twenty-four hours of murder, sniping, and massive piles of corpses left on the streets, the Egyptians do not rise up; it is the Knights of Malta who decide all of a sudden to leave Egypt. As he enacts his fateful mission and roams the streets of Cairo in a Buddha mask, we see how the effects of killing civilians have changed dramatically. At this stage, citizens accept gunshots with indifference and anticipation, as if sloughing off the burden of living.

Rabie paints a rather grotesque portrait of Egyptian society in 2025 Cairo, where verbal violence, violent sex, homicide among civilians, public suicides and death penalties, and the availability of weapons are pandemic. Violent death becomes a performance of horror to which the spectators contribute to escalate it. The major scene of the SpongeBob-masked naked man committing suicide is wholly telling. Making use of the "arena of spectacles" (Edwards 2007), ${ }^{7}$ the man decides to perform his own death naked on one of the busy bridges of Cairo. Arranging his props to perform the self-killing, he knots a thick rope, one end tied to the rail and the other around his neck, smiles to the crowd through the hole in the mask, then starts to "spit," "shake his hips," and "grin" at them. He succeeds in establishing the desired attention from the crowd, who are "flinging abuse at him and snorting derisively, and answering his shaking hips in kind. When he laugh[s] at them and wave[s], they laugh ... and wave" too (Rabī' 2014 , p. 96). To maintain the spectators' interactive engagement, he signals to the crowds with his first and middle fingers his urge to smoke, and a lighter and pack 
of cigarettes are thrown to him. Introducing his climax, he smokes calmly while balancing himself on the railing and playfully starting to urinate on the people below the bridge. Finally he jumps off, and his neck is broken by the rope. The scene of his corpse is quite absurd: his swaying body maintains a lighted cigarette and mix of urine and blood. The scene of death does not truly cease after the man's personal demise; on the contrary, it makes space for its continuation by inviting the crowds to actively take part in it. The spectators transform into performers when they start to thrash his corpse with "stones from the ground, pieces of wood, bags of trash, shoes, [and] tomatoes" (Rabī' 2014, p. 97). Later, some of them start to shoot at the rope, while the pellets spread on the corpse and the "unmoving" spectators. Finally, the rope breaks and people circle the deformed corpse. Unlike the scenes of death in 2011, the crowd shows no anger, fear, or empathy; the spectators are either pass by indifferently or participate grotesquely in such scenes. Death itself is no longer a source of terror, having become a public performance. In parts of "2025," violent death has been internalized by the people and is reciprocated among them. In this futuristic context, civilians instigate even more horrific deaths than the state does. This accentuates an extrapolated effect of violence and torture by allowing the normativity of violent death to prevail, which in turn provokes terror in the reader.

\section{Conclusion}

While Keraitim and Mehrez describe Tahrir Square as a "symbolic site of the birth of the [Egyptian's] freedom" (2012), in Otared it only brings death and annihilation. Four years after January 2011, Otared was published as an introspective view of the event and its reception and as an expression of anger and entrapment. This sense of entrapment stems from the fact that the matrix of the authoritarian regime is as unshakable as the theological notion of hell. As long as the likes of Otared are not held accountable, lives will continue to be ungrievable. This desperate realization, in turn, nullifies the potency of resistance. After January 25, 2011, dystopian novels have perceived the event as a dystopic moment at which false hope cost people their lives. It is too soon to predict how long the wave of post-2011 dystopias will last or how it will develop, but it is quite clear that the main aim of Rabie and his fellow authors is to deconstruct utopianizing discourses of the uprising as a way of commemorating the dead and acknowledging the suffering of the living. 


\section{Endnotes}

1. For further comments on the portrayal of the dead or martyrs (shuhadā') in Egyptian media according to the social class and appearance, see Mohammed Abou Al-Gheit's Al-fuqarā' awwalan yā wilād al-kalb [Poor First, you Bastards!] published 17 June 2011.

2. This part of the novel is a dramatization of a tale mentioned in the book 'Asha $B a$ 'da al-Mawt (Those Who Lived After Death) by 'Abd Allāh ibn Muhammad ibn Abi-l-Dunyā. In this book, ibn Abi-l-Dunyā collected tales about people who allegedly reawakened shortly after their deaths, only to die again. Rabie integrates the tale of Sahrr Ālhazrağy (one of the names mentioned in ibn Abi-l-Dunyā's book, who he died in $455 \mathrm{AH}$ and reawakened) to intensify the effects of suffering at the heart of the narrative. The incident of Ālhazrağy's double-death was believed to forebode the great famine that seized Egypt from 457 AH (1065 AD) to 464 AH (1072 AD) known as the "al-Mustanșiriyya Ordeal," referring to the Fatimid Caliph Abū Tamīm Ma'addal-Mustanșir bi-llāh, who ruled the country for sixty years (10361094). Mohammad Rabie mentions ibn Abi-l-Dunyā's book in acknowledgements of the Arabic original (p. 304).

3. Mulid is the Egyptian dialect pronunciation of Mawlid which is a festival made for celebrating the birth of Prophet Mohammed and/or the birth of a holy man or woman.

4. Keraitim and Mehrez "Mulid al-Tahrir: Semiotics of a Revolution," p. $25 \mathrm{ff}$.

5. This occupation lasts for two years. The Republic of the Knights of Malta does not really occupy a geographical space; they are mysterious remnants of the crusades who first took over Malta, where they got their name, then were expelled from there to take shelter in Rome. The Knights of Malta are bureaucrats, soldiers, and officers from all over the world; they speak Tunisian Arabic and English with different accents. They decide that Egypt could be a suitable place to practice land pirating. Their forces advance to the Egyptian heartland in 2023 by bombing strategic locations, such as the Central Bank, the ministries of Health and Education, the Cairo Opera House, and facilities and factories belonging to the Egyptian army across the country (p. $27 \mathrm{ff}$.).

6. In the original Arabic, Rabie uses the word "shaghab," a legal term designating disorderly conduct irregularities committed by rioters that undermine the rights of others and the public interest. The usage of the word, again, underlines the state's perspective in framing the collective protests of 2011 as illegal.

7. In her chapter "Death as Spectacle: Looking at Death in the Arena," Catherine Edwards traces the crowds' obsession with watching gladiators' deaths in the Roman Empire. She suggests that this obsession had roots in how Romans 
"found meanings in the bloody deaths of gladiators" (2007, p. 46), which are linked to their "attitudes of dying and representations of death in Roman antiquity" (Edwards 2007, p. 47).

\section{References}

Abou Al-Gheit, Mohammed. 2011. Al-fuqarā' awwalan yā wilād al-kalb [Poor First, you Bastards!]. Jidāriyya. https://bit.ly/1uX83jM. Accessed: 19 Feb 2019.

Butler, Judith. 2006. Precarious life: The powers of mourning and violence. London: Verso.

Currier, J.M., J.M. Holland, and R.A. Neimeyer. 2006. Sense-making, grief, and the experience of violent loss: Toward a mediational model. Death Studies 30 (5): 403-428. https://doi.org/10.1080/07481180600614351.

Edwards, Catharine. 2007. Death in Ancient Rome. New Haven: Yale University Press.

Keraitim, S., and S. Mehrez. 2012. Mulid al-Tahrir: Semiotics of a Revolution. In Translating Egypt's Revolution: The Language of Tahrir, ed. Samia Mehrez, 25-68. Cairo: The American University in Cairo Press.

Mittermaier, Amira. 2015. Death and Martyrdom in the Arab Uprisings: An Introduction. Ethnos 80 (5): 583-604. https://www.tandfonline.com/doi/pdf/10.1080/00141844.2014 .938090 ?needAccess $=$ true. Web. Accessed: 20 July 2019.

Norris, F.H. 1992. Epidemiology of trauma: Frequency and impact of different potentially traumatic events on different demographic groups. Journal of Consulting and Clinical Psychology 60 (3): 409-418. https://doi.org/10.1037/0022-006X.60.3.409.

Pannewick, Friederike. 2004. Introduction. In Martyrdom in Literature, ed. Friederike Pannewick, 1-26. Wiesbaden: Reichert Verlag.

Rabī', Muhammad. 2014. A 'Uțārid, 5th ed. Cairo: Dar al-Tanwīr.

Rabie, Mohammad. 2016. Otared. Trans. Robin Moger. Cairo: HoopoePrint.

Rynearson, Edward. 2013. Retelling Violent Death. Hoboken: Taylor and Francis. https:// gbv.eblib.com/patron/FullRecord.aspx?p=1112572. Accessed: 14 Nov 2019.

Walaa Said is a research fellow at the Institute of English and American Studies (IAA) at Philipps-Universität Marburg (Germany). The working title of her $\mathrm{PhD}$ dissertation is: "Crossing Borders and Breaking Rules in Dystopian Political Systems: A Cross-Cultural Study". Since 2018, she is also a research fellow at the Department of Arabic Studies at the Center for Near and Middle Eastern Studies at the same university. She is interested in borders, urban, and masculinity studies in relation to Egyptian, South African, and Canadian literatures. 
Open Access This chapter is licensed under the terms of the Creative Commons Attribution 4.0 International License (http://creativecommons.org/licenses/by/4.0/), which permits use, sharing, adaptation, distribution and reproduction in any medium or format, as long as you give appropriate credit to the original author(s) and the source, provide a link to the Creative Commons license and indicate if changes were made.

The images or other third party material in this chapter are included in the chapter's Creative Commons license, unless indicated otherwise in a credit line to the material. If material is not included in the chapter's Creative Commons license and your intended use is not permitted by statutory regulation or exceeds the permitted use, you will need to obtain permission directly from the copyright holder. 